\title{
TRADISI UPACARA BASIWAH DALAM MASYARAKAT HINDU KAHARINGAN DESA PENDREH
}

\author{
Santang \\ IAHN Tampung Penyang Palangka Raya \\ Santang.putir@gmail.com
}

\section{Riwayat Jurnal}

Artikel diterima $\quad: 8$ Juli 2019

Artikel direvisi : 25 Juli 2019

Artikel disetujui : 1 Agustus 2019

\begin{abstract}
Abstrak
Upacara Kematian merupakan salah satu upacara yang penting dalam kehidupan manusia. Salah satu tahapan yang penting dalam upacara kematian yang tidak dapat dilewatkan bagi masyarakat Desa Pendreh Kabupaten Barito Utara adalah Upacara Basiwah. Pada upacara ini para keluarga membersihkan diri dari pali yang sebelumnya terdapat dalam keluarga mereka. Upacara ini memiliki beberapa tahapan-tahapan yang dilaksanakan di hari pertama, hari kedua, dan hari ketiga. Seperti halnya upacara lainnya Upacara Basiwah memiliki sarana-sarana upacara untuk mendukung pelaksanaan upacara. Sarana ini antara lain jukung limit dan hampong. Penelitian ini dimaksudkan untuk membahas mengenai pengertian, tahap-tahap, dan sarana pada Upacara Basiwah. Kata kunci: upacara basiwah, jukung limit, hampong, pander jampa, batumbang.
\end{abstract}

\section{Pendahuluan}

Agama Hindu merupakan salah satu agama yang dianut oleh masyarakat Indonesia. Seperti halnya agama-agama lain di dunia, Agama Hindu memuja hanya satu Tuhan yang secara universal dikenal sebagai Brahman atau Paramatman. Namun bagi masyarakat awam, agama ini diartikan memuja banyak Tuhan yang sebenarnya dalam ajaran Hindu merupakan Brahman yang memanifestasikan diri sesuai dengan fungsi yang Beliau kehendaki. Hal yang membedakan Agama Hindu ini sebenarnya yang membentuk keberagaman dalam masyarakat Hindu yang telah diterima dan dipahami sebagai pluralitas. "Dan pluralitas merupakan kekuatan bagi Agama Hindu hingga sekarang ini" (Coward, 1992. hal. 167168).

Oleh sebab itu, masyarakat Hindu secara universal bisa menerima perbedaan budaya yang terdapat pada masyarakat Hindu yang berbeda antara masyarakat Hindu yang satu dengan masyarakat Hindu yang lain. Inilah yang menyebabkan terdapat begitu banyak cara dalam menjalani kehidupan dan juga jalan mencari kedamaian bagi masyarakat Hindu. "Malah dapat dikatakan jati diri atau identitas diri yang kemudian menjadi 
tradisi unik setiap agama besar lahir dari usaha menjawab tantangan lingkungan yang majemuk dimana agama-agama itu lahir" (Pandor, 2012: hal. 21).

Begitu puladengan lahirnya agama Hindu Kaharingan yang merupakan agama yang telah hadir di pulau Kalimantan sejak dahulu yang merupakan salah satu dari versi lokal Agama Hindu. Agama ini diyakini telah ada dan dikenal sebagai agama lama (helu) dalam masyarakat Dayak. Seperti yang dinyatakan dalam pernyataan yang ditulis dalam Hindu, T. P. B. P. A. (1996)berikut:

"Concerning the religious system of Dayak society who have various religious systems or beliefs that have existed since time immemorial, Dayak religion was called "helu" religion or formerly known as Hindu Kaharingan religion"

Kutipan di atas dapat diterjemahkan kurang lebih sebagai berikut:

"Mengenai sistem keagamaan masyarakat Dayak yang memiliki berbagai sistem atau kepercayaan agama yang telah ada sejak jaman dahulu, agama Dayak disebut agama helu atau agama yang sebelumnya dikenal sebagai agama Hindu Kaharingan”

Agama ini sebelumnya memang disebut sebagai agama helu atau agama sebelumnya sebelum terjadinya integrasi dengan agama Hindu. Setelah integrasi, 'Kaharingan' menjadi agama 'Hindu Kaharingan' yang ada sampai sekarang di Kalimantan Tengah (Penyang, et al, 2003:
10-11). Integrasi antara Hindu dengan Kaharingan akhirnya membuat Kaharingan dikenal dengan Hindu Kaharingan hingga sekarang.

Integrasi ini berlangsung didasari adanya paham bahwa Agama Hindu tidak mengenal satu (saja) sistem kepercayaan, figur tokoh, ritus, sesaji, sistem, jalan keselamatan, maupun tradisi. Ritus tertentu dipergunakan oleh beberapa tradisi sebagai hal penting demi keselamatan, namun ada yang hadir secara berdampingan. Hindu disebut sebagai agama paling tua dan paling rumit, namun paling mudah dilaksanakan (Dirjen Bimas Hindu, 2006 dalam Sugiyarto, 2016).

Hal ini dapat diterima oleh masyarakat Hindu karena begitu majemuknya lingkungan yang terdapat di Kalimantan khususnya di masyarakat yang menganut agama helu.Lingkungan yang majemuk (yang juga berarti begitu beragam) inilah yang membuat setiap versi lokal agama Hindu memiliki berbagai macam tradisi unik. Keberagaman ini merupakan hasil dari usaha masyarakatnya dalam beradaptasi dengan lingkungannya yang memiliki tantangan yang bermacam-macam. Penerimaan keberagaman yang selalu berusaha diterapkan oleh masyarakat Hindu ini karena masyarakat Hindu menyadari bahwa kedewasaan dalam beragama merupakan hal yang tidak boleh dilupakan.

Hal ini maksudnya adalah masyarakat Hindu menyadari bahwa masyarakat tertentu yang memiliki 
kepentingan bersama terbentuk karena adanya kesamaan cara dalam mengatasi tantangan di lingkungannya.

Whitehead (1967: 191) menyatakan bahwa

"Agama merupakan visi dari sesuatu yang melampaui, di balik dan di dalam, aliran perubahan sesuatu yang berlangsung cepat;sesuatuyang kemungkinan kecil, meskipun demikian antitesisterbesarnya diselesaikan dengan menentukan tipe urutan dengan kepentingan yang relatif berdasarkan keberhasilan mereka dalam meningkatkan keberadaan individu berdasarkan keadaan sebenarnya, bisa dikatakan, dengan mengembangkan kelebihan berupa keahlian"

Kutipan di atas dapat dimaknai bahwa agama adalah visi yang ada pada aliran perubahan yang melintas dengan begitu cepat, hal yang sepertinya kemungkinan kecil namun memiliki antithesis atau bisa disebut sebagai "cara mengatasi persoalannya" dengan menentukan tipe urutan dengan kepentingan relatif. Hal ini didukung dengan kemampuan dalam mengaktualisasi individu atau menemukan sisi pribadi terbaik pada setiap individu. Hal ini juga berarti mengembangkan keahlian individu tersebut.

$\begin{array}{lll}\text { Kesamaan kepentingan } & \text { yang } \\ \text { relatif berdasarkan tantangan } & \text { pada } \\ \text { wilayahnya masing-masing inilah } & \text { yang } \\ \text { nantinya akan menjadikan } & \text { suatu }\end{array}$

masyarakat memiliki tradisi atau kebiasan yang dilakukan secara turun-temurun yang khas pada setiap lingkungannya. Hal ini lah yang menciptakan hubungan unik dalam masing-masing kehidupan masyarakat. Inilah yang disebut oleh Heidegger (2001, 154-155) sebagai "Being-with-Others" dalam pernyataannya berikut:

“.... 'With' and 'too' are to be understood 'existentially', not 'categorially'. By reason of this 'with-like' [mithaften] "Being-inthe-world, the world is always the one that I share with others."

Pernyataan di atas dapat diterjemahkan kurang lebih sebagai berikut:

“.... 'Dengan' dan 'Juga' dipahami sebagai 'secara eksistensial', bukan 'secara kategori. Dengan alasan dari 'with-like' 'berada-di-dunia', dunia adalah selalu yang saya bagi bersama yang lain."

Pernyataan ini mengandung pengertian bahwa berada di dunia tidak sekedar hidup dan berada di suatu tempat, melainkan juga bermakna menjalin hubungan dengan yang lain. Oleh karena itulah, masyarakat pada umumnya akan menjalin hubungan dengan masyarakat lainnya.

Dalam kehidupan bermasyarakat terdapat berbagai hubungan yang menarik untuk dikaji. Salah satunya adalah hubungan yang menciptakan suatu sistem tertentu yang dapat menghasilkan suatu kebiasaan tertentu dalam kelompok masyarakat tertentu. Kebiasaan ini 
apabila dirasa oleh masyarakat tersebut dapat membantu keseimbangan kelangsungan hidup mereka biasanya tidak hanya akan sekedar menjadi suatu kebiasaan biasa malahan akan dijadikan suatu tradisi yang khas pada masyarakat tersebut.

".... This attribution tells us that as members of the "ingroup," we and others in the group act in certain ways and think in certain ways. It is what defines us, in a real sense."

Kutipan di atas dapat diterjemahkan kurang lebih sebagai berikut:

"Hubungan ini memberitahukan kepada kita bahwa sebagai anggota 'ingroup', kita dan yang lainnya dalam grup bertindak dengan cara tertentu dan berpikir dengan cara tertentu. Itulah yang membedakan kita, dengan secara nyata."

(Brown, 1996; Hogg, 1996; Tajfel, 1978 di dalam Straub, dkk, 2002: hal. 19)

Begitu pula halnya yang terjadi pada masyarakat Hindu Kaharingan Desa Pendreh yang berasal dari Desa Pendreh Kabupaten Barito Utara Kalimantan Tengah. Dalam masyarakat ini terdapat berbagai tradisi yang telah diwarisi secara turun-temurun dari nenek moyang mereka. Di antara berbagai tradisi ini terdapat salah satu tradisi yang unik yang dimiliki oleh masyarakat Desa Pendreh. Tradisi ini adalah tradisi Basiwah.

"Tradition was both the means of making a living and the symbols, stories, and memories which gave one both identity and status. So we can say that even in situations where society stayed almost the same from generation to generation, "tradition," or whatever people of that society might have called it in their own language, was something pretty central or important."

(Graburn, 2008: hal. 6-7)

Tradisi memberi identitas dan status pada seseorang dari generasi ke generasi. Tradisi merupakan sesuatu yang pokok yang juga penting bagi kelompok masyarakat. Dengan istilah lain, tradisi merupakan suatu unsur yang tidak terpisahkan dalam suatu budaya masyarakat.

Tradisi Basiwah memiliki pengertian salah satu bagian dari upacara kematian tahap akhir. Upacara Basiwah tidak merupakan upacara terakhir dalam berbagai tahapan upacara kematian masyarakat Desa Pendreh. Upacara terakhir dalam tahapan upacara kematian masyarakat Desa Pendreh disebut Wara. Sedangkan Basiwah merupakan tahapan sebelum Wara dilakukan.

Basiwah bagi masyarakat Desa Pendreh merupakan tahap melepas keterikatan sekaligus pembersihan diri. Hal ini berarti terdapat pembersihan semua keterikatan keluarga yang masih hidup dengan keluarga atau leluhur yang sudah meninggal. Sehingga apabila keluarga yang masih hidup akan melakukan upacara lain, misalnya upacara pernikahan, upacara tersebut dapat dilakukan dengan lancar. 
Masyarakat desa Pendreh seperti halnya masyarakat Dayak lainnya juga menjaga keharmonisan yang selama ini selalu mereka pertahankan.

"Orang Dayak dikenal sangat menjaga harmoni, sehingga mengenal tiga relasi yang harus dijaga keharmonisannya, yaitu: (1) Hubungan manusia dengan Ranying Hatalla, Penyang Ije Kasimpei, Penyang Ranying Hatalla Langit, artinya beriman kepada Yang Tunggal yaitu Ranying Hatalla Langit; Hubungan manusia dengan manusia lainnya, Hatamuei Lingu Nalatai. Artinya, saling kenal mengenal, tukar pengalaman dan pikiran, serta saling tolongmenolong. Hatindih Kambang Nyahun Tarung, Mantang Lawang Langit. Artinya, berlomba-lomba menjadi manusia baik agar diberkati Tuhan di langit serta bisa memandang dan menghayati kebesaran Tuhan; (3) Hubungan manusia dengan alam semesta, karena ciptaan Ranying Hatalla yang paling mulia dan sempurna adalah manusia."

(Sugiyarto, 2016: hal. 114)

Oleh karena itulah masyarakat desa Pendreh sampai sekarang masih mempertahankan tradisi Basiwah. Upacara ini juga merupakan salah satu upacara yang membantu keeratan hubungan antar keluarga di desa Pendreh. Upacara ini mencerminkan cara masyarakat dalam menjaga keharmonisan antara hubungan manudsia dengan Tuhan, manusia dengan manusia lainnya, dan manusia dengan alam atau yang dikenal dalam ajaran Hindu Bali dengan konsep Tri Hita Karana.

Upacara Basiwah ini juga memiliki tahapan-tahapan yang dilakukan selama prosesinya. Selain itu, upacara ini biasanya dilaksanakan selama tiga hari berturut-turut. Pelaksanaan upacara ini juga memiliki bahan-bahan yang diperlukan sebagai sarana dalam upacara. Semua ini akan dibahas pada bagian pembahasan.

Penelitian ini menggunakan pendekatan deskriptif kualitatif dan merupakan jenis penelitian empiris. Sumber data diperoleh dari data primer dan sekunder. Metode pengumpulan data diperoleh dengan metode pengamatan, wawancara dan rekam. Meted ananalisis data pada penelitian ini dilakukan dengan analisis deskriptif.

Hasil penelitian diperoleh berdasarkan wawancara yang dilakukan terhadap dua (2) orang narasumber yang merupakan Basir di Desa Pendreh.

Kedua narasumber memberikan pernyataan selama upacara berlangsung yaitu pada tanggal 4, 5, 6 Juni 2019 di Upacara Basiwah di Desa Pendreh Kabupaten Barito Utara.

\section{Pembahasan}

Seperti yang telah sering diketahui secara umum upacara kematian merupakan upacara yang sangat sakral dan merupakan penghormatan terhadap 
almarhum. Upacara ini dilaksanakan dengan berbagai tahapan yang beragam dalam setiap kelompok masyarakat. Upacara ini dapat diartikan sebagai melepas roh almarhum menuju Lewu Tatau atau tempat tujuan akhir roh almarhum sehingga dapat terlepas dari segala keterikatan dengan dunia. Namun sebelum upacara tahap akhir ini ada upacara lain yang perlu dilaksanakan oleh masyarakat Dayak.

Begitu pula halnya dengan masyarakat Hindu Kaharingan Desa Pendreh di Desa Pendreh Kabupaten Barito Utara Kalimantan Tengah. Masyarakat Desa Pendreh mengenal istilah Basiwah sebagai salah satu tahapan upacara kematian. Namun upacara ini tidak merupakan upacara terakhir melainkan upacara sebelum upacara kematian tahap akhir. Upacara ini juga dapat diartikan sebagai melepas keterikatan sekaligus membersihkan diri dari pali bagi keluarga yang di dalam keluarga terdapat anggota keluarga yang telah mengalami kematian. Sehingga, berbagai upacara yang ingin dilakukan setelah upacara ini dapat dilakukan dengan baik.

Upacara ini sarat akan kerjasama. Sehingga silahturahmi yang terjalin antar keluarga pun terjalin. Kesadaran untuk terus menjalin kebersamaan ini juga merupakan hal yang didasari oleh rasa berada di antara manusia lain. Seperti yang dinyatakan oleh Heidegger (1973: 162) "And that is possible only if Dasein, as Being-in-the-world, already is with Others" yang menekankan adanya kebersamaan dengan orang lain sebagai bagian dari keberadaan di dunia. Hal tersebut dapat dilihat dari adanya kebersamaan yang dibangun masyarakat desa Pendreh dalam melaksanakan upacara Basiwah.

Hasil wawancara mencakup pengertian Upacara Basiwah bagi masyarakat Desa Pendreh, sarana yang dipergunakan, dan tahapan-tahapan upacara selama Upacara Basiwah berlangsung. Berikut adalah uraian dari hasil wawancara dan pengamatan yang telah dilakukan.

\section{A. Pengertian Upacara Basiwah bagi Masyarakat Pendreh}

Upacara Basiwah ini berfungsi untuk membersihkan jiwa raga. Setelah upacara Basiwah ini terlaksana, keluarga yang telah ditinggalkan dapat melaksanakan upacara lain seperti halnya bila mereka akan melaksanakan upacara pernikahan. Setelah mereka melakukan pembersihan maka mereka dapat melanjutkan kehidupannya dan melaksanakan upacara-upacara lainnya.

Walaupun misalnya keluarga yang terlibat dalam Upacara Basiwah pada mulanya hanya sedikit namun biasanya akan ada keluarga lain yang juga ingin ikut terlibat pada upacara ini. Waktu pelaksanaanya pun tidak diwajibkan setiap frekuensi waktu tertentu. Namun baru akan dilaksanakan apabila para keluarga sudah merasa memiliki dana yang cukup untuk pelaksanaan upacara.

Hal ini juga berlaku untuk waktu dimulainya pelaksanaan upacara 
Basiwah. Tidak ada tanggal yang dipastikan untuk pelaksanaannya namun biasanya dilaksanakan setelah warga selesai manggetem (panen padi). Yaitu sekitar bulan Juni hingga bulan Juli.

Sebelum upacara dimulai para keluarga yang terlibat berbicara untuk menyatukan kesepakatan dalam pelaksanaan upacara Basiwah ini. Pembicaraan ini untuk merundingkan pelaksanaan upacara di antara keluargakeluarga yang ikut upacara. Dalam pembicaraan ini para keluarga juga melibatkan kepala desa. Mereka akan memberitahukan kepada kepala desa bahwa akan dilaksanakan upacara Basiwah. Setiap keluarga akan memiliki satu (1) perwakilan untuk berbicara dalam pembicaraan ini. Sehingga setiap perwakilan akan mendapat kesempatan untuk berbicara. Setelah dicapai kesepakatan barulah upacara Basiwah diselenggarakan.

Dalam upacara Basiwah terdapat proses Mandi Air Limit. Mandi Air Limit ini berfungsi untuk membersihkan pali dari anggota keluarga yang keluarganya ada yang mengalami kematian. Tujuannya adalah agar jiwa raga anggota keluarga tersebut dapat dibersihkan sehingga dapat melaksanakan upacara lainnya.

Peserta yang ikut upacara Basiwah umumnya adalah para keluarga yang berasal dari Desa Pendreh, Kabupaten Barito Utara. Sebanyak 37 keluarga ikut serta dalam upacara ini kali ini. Ada yang mengembalikan barang yang dulunya diperoleh dari kerabat lain dalam upacara basiwah sebelumnya. Ada pula yang menerima maupun memberi barangbarang.

\section{B. Sarana Upacara Basiwah}

Dalam upacara basiwah terdapat beberapa sarana upacara yang digunakan. Antara lain sarana yang digunakan baik pada saat mandi air limit dan juga pada saat menari. Berikut adalah beberapa sarana yang digunakan dalam upacara Basiwah.

Dalam upacara Basiwah akan disediakan "Jukung" (perahu tradisional) yang diisi air kunyit. Jukung ini bisa menggunakan jukung kecil maupun jukung besar. Jukung yang digunakan pun boleh jukung biasa yang digunakan sehari-hari. Jukung itu disebut "jukung limit" dan airnya disebut "air limit". Air limit adalah air yang dicampur kunyit yang telah dilumatkan dan dicampur di dalamnya.

Sarana mandi Air Limit antara lain adalah Jukung Limit yang telah diisi dengan Air Limit. Selain itu di sisi kiri dan kanan Jukung Limit terdapat pagar kayu. Pagar kayu ini akan dipasang bendera-bendera dengan kain bahalai. Di masing-masing bendera terdapat beberapa benda yang digantung di tiang bendera yang telah ditancapkan di pagar kayu. Benda-benda ini antara lain kelapa muda (wajib menggunakan kelapa muda), kue tradisional, lamang (ketan yang dimasak di dalam bambu), telur, dan tebu. Bendabenda ini adalah syarat yang diperlukan dalam mandi air limit. 
Selain itu terdapat pula hampong yang diletakkan ditengah-tengah ruangan yang akan dijadikan tempat untuk menari oleh para peserta upacara Basiwah. Hampong ini kemudian akan dikelilingi sambil menari oleh para peserta upacara. Hal ini untuk melepas pali atau sial.

\section{Tahapan-tahapan Upacara Basiwah}

Tahapan-tahapan Upacara Basiwah dilaksanakan terbagi menjadi tiga (3) bagian. Ketiga bagian ini dibagi berdasarkan hari dilaksanakannya Upacara Basiwah. Pada bagian pertama dilaksanakan pada hari pertama, begitu pula bagian kedua dan ketiga dilaksanakan berturut-turut pada hari kedua dan ketiga.

Pada bagian pertama yang dilaksanakan pada hari pertama terdapat proses "mijom apui" yaitu para keluarga berkumpul di rumah tempat berbicara. Kemudian mereka akan melakukan "pander jampa" yaitu berbicara dalam forum antara masyarakat kampung tersebut dengan para tetua adat. Masingmasing keluarga memiliki satu perwakilan untuk berbicara satu persatu. Mereka akan menyebutkan nama-nama almarhum yang akan diberikan upacara mijom apui (Bahasa: Desa Bayan). Mijom apui ini jika diartikan kata perkata bermakna sebagai berikut:

Mijom : memadamkan

Apui : api

Namun, sebenarnya ini adalah istilah atau kiasan yang bermakna menyelesaikan urusan almarhum dengan hubungan duniawi. Ini adalah tahap awal proses melepaskan ikatan almarhum dengan kehidupannya sebelumnya. Tahap ini kemudian akan dilanjutkan proses berikutnya. Semenjak pander jampa maka saat itulah mijom apui dimulai. Pander jampa dilaksanakan sampai sore atau malam hari. Setelah selesai maka dalam pander jampa akan disampaikan bahwa keesokan harinya akan ada kegiatan selanjutnya. Kemudian para peserta basiwah akan pulang ke rumah masing-masing.

Pada bagian kedua yang dilaksanakan pada hari kedua para peserta basiwah akan berkumpul kembali. Selanjutnya merekan melakukan pander jampa. Mereka akan membicarakan kepada kepala desa dan tetua adat perihal “malik tuung gendering”.

$\begin{array}{ll}\text { Malik } & \text { : membalik } \\ \text { Tuung } & \text { : gendang } \\ \text { Gendering } & : \text { gong } \\ \text { Malik tuung } & \text { gendering bermakna }\end{array}$
membalik gong yang sebelumnya ditaruh terbalik, yaitu bagian muka gong yang biasa dipukul ditaruh menghadap ke bawah dan bagian belakangnya menghadap ke atas. Walaupun terdapat kata tuung namun sebenarnya yang dibalik disini hanya gong saja tanpa ada pembalikan gendang.

Proses ini dilakukan agar gong tersebut dapat digunakan kembali dalam pelaksanaan acara lainnya. Gong ini terdapat empat (4) buah. Gong-gong ini disediakan di rumah tempat berlangsungnya upacara Basiwah. Pemilik gong biasanya adalah peserta 
basiwah. Apabila mereka tidak memiliki mereka dapat meminjam dari keluarga yang memiliki gong. Setelah pander jampa maka selanjutnya dilanjutkan dengan pelaksanaan malik tuung gendering dapat dilakukan.

Setelah pelaksanaan malik tuung gendering para peserta Upacara Basiwah akan mandi air limit dalam jukung limit. Proses ini dimaksudkan untuk membersihkan diri. Pada tahap ini para keluarga memberi maupun menerima tumbang atau barang-barang yang merupakan tanda bahwa mereka telah melakukan upacara basiwah.

Pemberian maupun penerimaan tumbang ini dilakukan untuk saling mendukung, sepakat, dan menciptakan kerukunan antar keluarga. Misalnya pada saat upacara basiwah sebelumnya mereka diberikan barang-barang tersebut oleh keluarga lain sebagai tanda keluarga yang memberikan barang-barang tersebut sudah melaksanakan basiwah. Kemudian mereka yang menerima barang akan mengembalikannya pada saat upacara Basiwah kali ini. Barang-barang yang dikembalikan antara lain sebuah piring, selembar kain bahalai, lamang, tebu, gula merah, telur, kelapa muda, dan kue tradisional. Pengembalian barang ini harus sesuai dengan yang dulu diberikan. Hal ini biasanya merupakan tanda bahwa keluarga tersebut sudah melaksanakan Upacara Basiwah.

Sebutan untuk istilah ini adalah batumbang. Pada proses mengembalikan barang disebut mengembali tumbang dan menerima barang atau menerima tumbang para keluarga akan mandi air limit terlebih dahulu. Pada saat proses inilah para keluarga melaksanakan proses patumbang keluarga lain dengan cara memberi tumbang dan ada pula keluarga yang menerima tumbang.

Pada proses ini para keluarga akan mandi terlebih dahulu di dalam sebuah jukung yang telah diisi dengan air limit. Tujuannya adalah membersihkan diri. Proses batumbang ini rutin dilakukan dan terus berkelanjutan hingga upacaraupacara basiwah yang akan datang. Namun apabila ada keluarga yang belum mampu tidak didesak secepatnya melainkan sampai ia memiliki kemampuan yang cukup untuk melaksanakan batumbang pada upacara basiwah lainnya. Setelah mandi air limit parakeluarga akan mengambil tumbang untuk dibawa ke rumah masing-masing.

Setelah mandi air limit para keluarga peserta Basiwah akan menari mengelilingi hampong. Hampong adalah wadah yang dibuat menyerupai kotak yang dibungkus kain dan diletakkan di tengah-tengah rumah salah satu keluarga peserta Basiwah yang dekat dengan lokasi mandi air limit. Di tepian sompung terdapat tengkorak kepala manusia. Tengkorak ini sudah turun-temurun diwariskan. Dulunya tengkorak tersebut berupa kepala yang diperoleh dalam mangayau (penggal kepala). Kemudian disimpan dipergunakan untuk disapukan ke semua orang yang ikut upacara Basiwah sebelum mandi air limit. Oleh karena lamanya waktu berlalu setelah 
disimpan turun-temurun, kepala manusia tersebut kini tersisa tengkorak.

Setelai selesai menari mengelilingi Hampong, kegiatan selanjutnya adalah pengurbanan babi yang telah dipersiapkan sebelumnya. Babi ini adalah hewan kurban yang disediakan dan nantinya akan dimasak dan disajikan dalam makan bersama setelah upacara selesai. Setelah itu orang-orang akan kembali ke rumah masing-masing dan mempersiapkan untuk kembali lagi pada sore menjelang malam hari.

Setelah upacara selesai, keluarga yang telah mengembalikan barang maupun yang dikembalikan barangnya akan memberitahu pengembalian telah dilaksanakan. Begitu pula keluarga yang telah menerima barang maupun memberi barang juga akan mengabarkan bahwa proses ini telah dilaksanakan. Pemberitahuan ini dilakukan setelah proses mandi limit yaitu pada malam hari pada saat para keluarga berkumpul kembali pada pander jampa.

Pada malam harinya para anggota keluarga akan berkumpul dan duduk mengelilingi ruangan yang disediakan. Dalam tahap ini para anggota keluarga akan meminum tuak tradisional yang disajikan dalam tanduk kerbau sepanjang kurang lebih $30 \mathrm{~cm}$. begitu tiba giliran untuk meminum tuak, anggota keluarga yang telah hadir harus meminum tuak tersebut sampai habis. Peserta yang ikut meminum tuak ini tidak dibatasi baik laki-laki maupun perempuan. Bahkan apabila ada warga lain yang ingin ikut walaupun bukan merupakan peserta upacara Basiwah pun dipersilahkan untuk ikut. Bagi anggota keluarga atau pun warga yang tidak mampu minum tuak tidak diwajibkan untuk ikut serta minum dalam tahap ini. Selain itu mereka juga akan makan ayam dan lamang yang telah digantung di dalam rumah tersebut. Pada tahap ini setiap perwakilan dari para keluarga akan berbicara mengabarkan bahwa upacara Basiwah mereka telah selesai dilaksanakan. Begitu pula keluarga yang mengembalikan barang maupun keluarga yang barangnya telah dikembalikan juga akan berbicara memberitahukan bahwa proses pengembalian barang telah terlaksana dalam upacara tersebut.

Pada bagian ketiga yang dilaksanakan pada hari ketiga yaitu keesokan paginya akan dilanjutkan kegiatan berbicara lanjutan yang dilakukan oleh para keluarga pada forum pander jampa. Kegiatan ini disaksikan oleh para tetua adat. Pemberitahuan ini memberitahukan bahwa para keluarga telah selesai melaksanakan upacara basiwah. Hal ini juga berarti para keluarga telah lepas dari pali atau pantangan. Sehingga mereka dapat melakukan kegiatan lain yang sebelumnya masih dipantangkan. Setelah lepas pali mereka dapat melakukan acara yang sifatnya meriah atau pesta pora. Pada saat ini pula semua gong yang telah digantung setelah malik tuung grinding akan dilepas dan disimpan oleh pemiliknya atau pihak keluarga.

Dalam upacara Basiwah ini terdapat penanda bagi keluarga yang telah 
melaksanakan Basiwah untuk keluarganya yang telah meninggal. Penanda tersebut berupa kain bahalai yang dipasang sebagai bendera di depan rumah keluarga tersebut. Oleh karena itulah keluarga yang ikut mandi di air limit karena barangnya dalam menerima tumbang tidak memasang bendera di depan rumahnya.

\section{Penutup}

Upacara Basiwah bagi masyarakat Desa Pendreh merupakan upacara yang begitu sakral sehingga menghasilkan berbagai tahapan upacara kematian. Dengan adanya Upacara Basiwah ini keluarga yang tadinya masih terikat pali dapat membersihkan diri dari pali dan dapat melaksanakan upacara-upacara lainnya. Upacara ini tidak hanya untuk membersihkan diri dari pali, namun juga menghasilkan hubungan yang harmonis antar keluarga yang ditinggalkan. Sehingga keluarga yang ditinggalkan dapat tetap bersatu dan bekerja sama dalam suatu hubungan kekerabatan yang begitu erat.

Upacara Basiwah hendaknya terus dilestarikan sebab tidak hanya untuk mempertahankan tradisi leluhur, upacara ini juga menampilkan adanya kebersamaan dalam pelaksanaannya. Kebersamaan ini terlihat dari awal mula perencanaan, selama berlangsungnya upacara, maupun akhir upacara yang selalu diiringi dengan pander jampa untuk mencapai kesepakatan bersama. Selain itu juga ada tradisi keharusan memberikan bahan-bahan upacara, seperti kain bahalai, piring, kelapa muda dan lain-lain, dari keluarga satu ke keluarga lain dalam upacara Basiwah menyebabkan antar keluarga belajar saling tolong-menolong disaat keluarga lain membutuhkan bantuan.

Teriakhir penulis menyampaikan terima kasih kepada masyarakat desa Pendreh yang telah mengizinkan penulis untuk menuliskan dan mendokumentasikan tradisi leluhur ini dalam bentuk artikel. Serta tidak lupa penulis sampaikan terima kasih kepada para narasumber dan warga yang telah membantu proses wawancara selama penelitian berlangsung. Semoga tulisan ini dapat bermanfaat untuk ke depannya dan dapat memberikan kontribusi bagi masyarakat umum dan masyarakat desa Pendreh secara khususnya.

\section{Lampiran}

Berikut adalah narasumber yang telah diwawancarai pada upacara Basiwah di Desa Pendreh.

1. Nama : Wiliam

Pekerjaan : Pensiunan PNS

Keahlian : Mantir Adat, Basir

Usia : 68 tahun

2. Nama : Lihan

Pekerjaan : Swasta

Keahlian : Basir

Usia : 57 tahun

\section{Daftar Pustaka}

Coward, Harold, Pluralisme. 1992. Tantangan Bagi Agama-Agama. Yogyakarta: Kanisius. 
Graburn, Nelson H. H. 2016. What is

Tradition? Museum Anthropology 24(2/3):6-11. Copyright C2001 American Anthropological Association. Diunduh pada 01/07/2019

[file:///C:/Users/ACER/Download s/mua.2000.24.2-3.6\%20(1).pdf]

Heidegger, Martin. 2001. Being and Time. Blackwell Publishers Ltd. 108 Cowley Road, Oxford OX4 1 JF, UK.

Hindu, T. P. B. P. A. (1996). Buku Pendidikan Agama Hindu untuk Perguruan Tinggi. Jakarta: Hanoman Sakti.

Pandor, Pius. 2012. Fenomenologi Agama Menuju Penghayatan Agama yang Dewasa. Jurnal Filsafat Aretévolume 7, No. 1 (2018). Surabaya: Fakultas Filsafat Unika Widya Mandala.

Penyang, Simal, dkk. (2003). Bahan Ajar Panaturan I. Palangka Raya: STAHN-TP.

Straub, D., Loch, K., Evaristo, R., Karahanna, E., Strite, M. 2002. Toward a Theory-Based Measurement of Culture. Journal of Global Information Management. Volume 10 No. 1. Idea Group Publishing.

Sugiyarto, Wakhid. 2016. Eksistensi Agama Hindu Kaharingan di Kota Palangka Raya Kalimantan Tengah. Peneliti Puslitbang Kehidupan Keagamaan Badan Litbang dan Diklat Kementrian Agama.
Whitehead A. North. 1967. Science and the Modern World. New York: The Free Press. 